Cadernos de Filosofia Alemã 4, Pp. 89-106, 1998

\title{
Ainda alguns esclarecimentos sobre a filosofia kantiana*
}

\author{
Arthur Schopenhauer \\ Tradução de Maria Lúcia Cacciola**
}

\begin{abstract}
Apresentação
Este texto (Noch einige Erläuterungen zur kantischen Philosophie) faz parte do capítulo 13 dos Fragmentos sobre a história da filosofia (Fragmente zur Geschichte der Philosophie) que, por sua vez, integram os Parerga $e$ Paraliponema (Parerga und Paraliponema), obra em dois volumes editada em Berlim no ano de 1851. No prefácio, Schopenhauer adverte que essa obra inclui dissertações paralelas à sua obra sistemática, dentre as quais figura como texto capital $O$ mundo como vontade e representação (Die Welt als Wille und Vorstellung). São textos sobre temas variados, que o autor diz não ter incluído na sua obra capital, quer por não encontrarem, tendo em vista seu conteúdo, um lugar nela, quer por terem sido escritos posteriormente. Schopenhauer explica que esses textos complementares trazem esclarecimentos ao leitor já familiarizado com sua obra sistemática anterior. Mas acrescenta que "no todo, o conteúdo desses volumes, com exceção de algumas passagens, será também compreensível e proveitoso para quem não tiver tal conhecimento”. Aliás,
\end{abstract}

\footnotetext{
* Do original "Fragmente zur Geschichte der Philosphie". In: Parerga und Paraliponema. Em: Sämtliche Werke, Band IV. Herausgegeben von W. F. von Löhneysen, Darmstadt, 1974.

** Professora do Departamento de Filosofia da FFLCH-USP.
} 
num esboço a um prefácio anterior, o autor mesmo explica que, à diferença de uma parte do segundo volume da obra (os Paraliponema), o volume dos Parerga, na sua totalidade, não pressupõe o conhecimento de sua filosofia, embora as referências a ela sejam constantes.

$\mathrm{Na}$ introdução aos Fragmentos sobre a história da filosofia, Schopenhauer diz tratarem-se de pensamentos ocorridos durante o estudo das obras originais e não copiados de outros e de compêndios da história da filosofia. Schopenhauer critica aí duramente as histórias da filosofia que estavam surgindo em seu tempo e que, em vez dos próprios pensamentos dos filósofos, trazem estes resumidos e acompanhados pelo juízo precipitado de algum professor de filosofia, que se esforça por lhes dar uma "tornure moderna", tentando além disso fundar "a necessidade do surgimento e da sucessão dos sistemas filosóficos". É a leitura dos próprios filósofos que Schopenhauer recomenda vivamente, já na abertura de seu texto: "Ler, em vez das próprias obras dos filósofos, variadas exposições de suas doutrinas ou a história da filosofia em geral é o mesmo que querermos que alguém mastigue a nossa comida".

Os Esclarecimentos sobre a filosofia kantiana aqui parcialmente traduzidos referem-se principalmente ao complemento à primeira edição do Mundo como vontade e representação, que se intitula Crítica da filosofia kantiana (Kritik der kantischen Philosophie) (Trad. Maria Lúcia Cacciola, São Paulo, Abril, 1978)*.

Maria Lúcia Cacciola

\footnotetext{
* A tradução integral dos Fragmentos, realizada pela mesma autora, deverá ser publicada este ano pela editora Iluminuras de São Paulo.
} 
Como mote da Crítica da Razão Pura, seria muito apropriada uma passagem de Pope (Works, vol 6, p. 374, Ed. Baseler) escrita mais ou menos oitenta anos antes dela: "since its reasonable to doubt most things, we should most of all doubt that reason of ours which would demonstrate all things" ("desde que é razoável duvidar da maioria das coisas, deveríamos acima de tudo duvidar de nossa própria razão a quem caberia demonstrar todas as coisas") [grifos do autor].

O espírito próprio da filosofia kantiana, seu pensamento fundamental e seu sentido verdadeiro, pode ser apreendido e exposto de múltiplas maneiras: estas diferentes versões e expressões do assunto serão umas mais apropriadas que outras, de acordo com a diversidade das cabeças, para abrir para este ou aquele o correto entendimento daquela doutrina muito profunda e, por isso, difícil. O que se segue é mais uma tentativa desta espécie, que se propõe lançar minha clareza na profundidade kantiana.

À matemática subjazem intuições, sobre as quais suas provas se apóiam: mas, dado que estas intuições não são empíricas, suas teorias são apodíticas. A filosofia, ao contrário, tem meros conceitos como sendo o dado de que ela parte, o qual deve comunicar necessidade (apoditicidade) a suas provas. Ela não pode pois contar diretamente com intuições meramente empíricas, porque se propõe a esclarecer o universal das coisas e não o particular, sendo sua intenção conduzir para além do empiricamente dado. Então lhe restam apenas os conceitos universais, já que estes, é claro, não são o intuitivo, puramente empírico. Tais conceitos têm, portanto, de fornecer a fundamentação de suas doutrinas e provas e se tem de partir deles como sendo um existente e um dado. Assim, por causa disso, a filosofia é uma ciência de meros conceitos; enquanto a matemática é uma ciência da construção (exposição intuitiva) de seus conceitos. Todavia, estritamente falando, é só a argumentação da filosofia que parte de meros conceitos. A saber, esta não pode, igual à matemática, partir de uma intuição, pois esta teria de ser ou a pura a priori ou a empírica: a última não dá nenhuma apoditicidade e só a Matemática fornece a primeira. Por isso, se ela porventura quiser apoiar suas doutrinas em demonstrações, então estas têm de consistir na inferência lógica correta a partir de conceitos postos como fundamento. - Deste modo, as coisas caminharam muito bem durante toda a longa escolástica e até mesmo na nova época fundada por Descartes, de tal modo que vemos ainda Espinosa e Leibniz seguir esse método. 
Porém, ocorreu por fim a Locke investigar a origem dos conceitos e o resultado foi que todos os conceitos universais, por mais amplos que possam ser, são hauridos da experiência, quer dizer, do mundo empírico real, sensível e intuitivo que está diante de nós, ou também da experiência interna, tal como a auto-observação a oferece a cada um, tendo com isso todo o seu conteúdo apenas a partir delas, não podendo conseqüentemente oferecer mais do que a experiência externa e interna aí colocou. Teria de ter sido rigorosamente inferido daí que eles nunca poderiam levar além da experiência, isto é, nunca poderiam levar ao alvo: mas Locke foi além da experiência com princípios hauridos da experiência.

Continuando a oposição a seus predecessores e corrigindo a doutrina lockiana, Kant então mostra que, na verdade, existem alguns conceitos que constituem uma exceção à regra acima, não se originando portanto na experiência. Mas ao mesmo tempo também mostra que mesmo estes conceitos são em parte hauridos das intuições puras, quer dizer, a priori, do espaço e do tempo, e, em parte, constituem as funções peculiares a nosso próprio entendimento, com o propósito de seu uso na experiência, que é regulada por eles. Mostra que, desse modo, sua validade se estende apenas à experiência possível mediada sempre pelos sentidos, desde que eles mesmos só são destinados a gerar em nós, pelo estímulo da impressão sensorial, esta experiência, juntamente com o seu procedimento conforme a leis. Mostra que estes conceitos, portanto, que em-si-mesmos são sem conteúdo, recebem toda matéria e forma somente da sensibilidade para depois, com elas, produzir a experiência. Excluída porém a experiência, eles não têm qualquer conteúdo ou significado, desde que só são válidos sob a pressuposição da intuição que repousa sobre a impressão sensorial, referindo-se essencialmente a ela. Daí se segue que não podem nos propiciar os guias para levar-nos para além da possibilidade da experiência e, ainda, que a metafísica, enquanto ciência daquilo que está além da natureza, quer dizer, além da possibilidade da experiência, é impossível.

Como uma das partes componentes da experiência, a saber, a universal, formal e legal, é cognoscível a priori, repousa por isso mesmo sobre as funções essenciais e legais do nosso próprio intelecto. A outra parte, pelo contrário, a saber, a particular, material e contingente, surge da impressão sensorial. Ambas são, pois, de origem subjetiva. Segue-se daí que o conjunto da experiência, junto com o mundo que nela se apresenta, é um mero fenômeno, quer 
dizer, algo que existe primeira e imediatamente só para o sujeito que o conhece. Todavia, esse fenômeno aponta para alguma coisa-em-si-mesma que está no seu fundamento, a qual, no entanto, é, como tal, simplesmente incognoscível. - Estes são os resultados negativos da filosofia kantiana.

Tenho de lembrar aqui que Kant faz como se fôssemos apenas seres que conhecem e que, portanto, não tivéssemos nenhum dado fora da representação. Enquanto que certamente possuímos em nós um outro dado, toto genere diverso daquele, que é a vontade. Ele, por certo, também a levou em consideração, não na filosofia teórica, mas meramente na filosofia prática, que nele é totalmente separada daquela. A saber, considerou a vontade, única e exclusivamente para estabelecer o fato da pura significação moral de nossos atos e para fundamentar aí uma doutrina de fé moral, como contrapeso da ignorância teórica, consequientemente também da impossibilidade de toda teologia, na qual caímos pelo que foi dito acima.

A filosofia de Kant, à diferença de todas as outras, e até mesmo em oposição a elas, é chamada de filosofia transcendental, mais precisamente de idealismo transcendental. A expressão "transcendente" não é de origem matemática, mas filosófica, pois já era corrente na escolástica. Ela foi introduzida na matemática, pela primeira vez, por Leibniz, para indicar "quod algebra transcendit" (o que transcende a possibilidade da álgebra), portanto todas as operações que a álgebra e a matemática normais não bastam para resolver, como, por exemplo, encontrar o logaritmo de um número ou vice-versa, ou encontrar, de modo puramente aritmético, as funções trigonométricas de um arco ou vice versa; em geral, todos os problemas que têm de ser resolvidos por um cálculo que prossegue indefinidamente. Os escolásticos chamavam porém de transcendentes os conceitos mais elevados, a saber, aqueles que eram ainda mais gerais do que as dez categorias de Aristóteles. Espinosa ainda usa a palavra nesse sentido. Giordano Bruno (Della Causa, principio ed uno, dial. 4) nomeia transcendentes os predicados que são mais gerais do que a diferença entre substâncias corpóreas e incorpóreas e que cabem, portanto, à substância em geral: dizem respeito, de acordo com ele, àquela raiz comum, na qual o corporal é uno com o incorporal e que é a verdadeira substância originária, e ele vê justo aí uma prova de que deve haver tal substância. Finalmente Kant entende, primeiramente, por transcendental, o reconhecimento do apriorístico e, por isso, do meramente formal no nosso conhecimento, como sendo tal. 
Quer dizer, a compreensão de que tal conhecimento é independente da experiência e de que é esse mesmo conhecimento que prescreve as regras inalteráveis segundo as quais esta tem de dar-se, ligada ao entendimento do porquê tal conhecimento é este e tem tal poder, a saber, porque ele constitui a forma de nosso intelecto: o que se dá como conseqüência de sua origem subjetiva. De acordo com isso só a Crítica da razão pura é propriamente transcendental. Em oposição a isto, ele chama de transcendente o uso, ou melhor, o abuso daquele elemento formal puro além da possibilidade da experiência, designando-o também como hiperfísico. Em suma, de acordo com isso, transcendental quer dizer o mesmo que "antes de toda experiência", transcendente, em contrapartida, "além de toda experiência". Assim Kant só admite a metafísica enquanto filosofia transcendental, quer dizer, como a teoria daquilo que, sendo formal, está contido enquanto tal em nossa consciência cognoscente e da limitação daí decorrente, em virtude da qual o conhecimento da coisa-emsi nos é impossível, desde que a experiência só nos pode fornecer meros fenômenos. A palavra "metafísico" não é todavia nele perfeitamente sinônima de "transcendental", sendo, aliás, chamado por ele de metafísico tudo que é a priori certo, mas referente à experiência; em contrapartida, só o ensinamento de que o que é certo a priori o é por causa de sua origem subjetiva e enquanto puramente formal, é que é chamado de transcendental. Transcendental é a filosofia que traz à consciência o fato de que as leis primeiras e essenciais deste mundo que se nos apresenta enraízam-se em nosso cérebro e, por causa disso, são conhecidas a priori. Ela chama-se transcendental porque vai além de toda fantasmagoria dada, até suas origens ${ }^{1}$. Portanto, como já dito, só a Crítica da razão pura e a filosofia crítica em geral (i.e., a kantiana) são transcendentais ${ }^{3}$; metafísicos, em contrapartida são os Princípios metafísicos da ciência da natureza, também os da Doutrina da virtude etc...

O conceito de uma filosofia transcendental pode entretanto ser ainda compreendido num sentido mais profundo, quando nos empenhamos em concentrar-nos no espírito mais íntimo da filosofia kantiana, mais ou menos da maneira que se segue: que o mundo nos é dado só de uma maneira secundária como representação, imagem na nossa mente, fenômeno cerebral, enquanto que a própria vontade nos é dada imediatamente na consciência de si; que, portanto, tem lugar uma separação, e mesmo uma oposição entre nossa própria existência e a do mundo - esta é uma mera conseqüência da nossa exis- 
tência individual e animal, com cujo término ela portanto desaparece. Até este ponto, porém, é impossível para nós suprimir no pensamento aquela forma fundamental e originária de nossa consciência, que é indicada como divisão em sujeito e objeto. Isto porque todo pensar e representar a tem como pressuposto. É por isso que a deixamos ficar e a admitimos sempre como a essência originária e a constituição fundamental do mundo, enquanto que, de fato, é apenas a forma de nossa consciência animal e o fenômeno mediado por ela. Mas, a partir daí, surgem todas aquelas perguntas sobre o começo, o fim, os limites e o nascimento do mundo, sobre a nossa própria duração após a morte e assim por diante...Todas elas repousam, pois, sobre um pressuposto falso, o de que aquilo que tem apenas a forma do fenômeno, quer dizer, que só é uma representação mediada por uma consciência animal cerebral, é atribuído à coisa em si mesma e é assim tomado pela constituição originária e fundamental do mundo. Este é o sentido da expressão kantiana : todas estas perguntas são transcendentes. Elas são por isso irrespondíveis, não apenas subjetivamente, mas em e por si mesmas, i. e. objetivamente. Pois são problemas que desaparecem completamente com a supressão de nossa consciência cerebral e das oposições que nela se baseiam; e que, no entanto, foram colocadas como se fossem independentes dela. Quem, por exemplo, pergunta se sobreviverá após a sua morte, suprime in hypothesi a sua consciência animal cerebral; está todavia perguntando por algo que só existe sob pressuposição da mesma, já que repousa sobre a sua forma, a saber, sujeito, objeto, espaço e tempo; a saber, pergunta pela sua existência individual. Assim, uma filosofia que traz à consciência todas estas condições e limitações enquanto tais, é transcendental e, enquanto reivindica para o sujeito as determinações fundamentais universais do mundo objetivo, é um idealismo transcendental. - Aos poucos, ver-se-á que os problemas da metafísica só são insolúveis, na medida em que uma contradição estiver contida nas próprias perguntas.

Entretanto, o idealismo transcendental não torna inteiramente contestável o mundo que se apresenta na sua realidade empírica, mas afirma apenas que esta não é algo de incondicionado, pois tem como condição nossas funções cerebrais, a partir das quais surgem as formas da intuição, portanto o tempo, o espaço e a causalidade - e que, por isso, esta realidade empírica é apenas a realidade de um fenômeno. Assim, quando nela se expõe uma multiplicidade de entes, dos quais sempre um desaparece e o outro nasce, sabemos 
que só mediante a forma da intuição do espaço é possível a multiplicidade, mediante a forma da intuição do tempo, o desaparecer e o nascer. Reconhecemos então que um tal processo não tem uma realidade absoluta, isto é, que ele não pertence ao ser em-si-mesmo que se expõe naquele fenômeno. Pelo contrário, se pudéssemos retirar aquelas formas de conhecimento como o vidro do caleidoscópio, teríamos diante de nós, para nosso espanto, esse ser-em-si como algo único e permanente, como imperecível, imutável e idêntico sob todas as mudanças aparentes e, talvez, até mesmo descendo às suas determinações bem particulares. De acordo com este modo de ver, podem-se estabelecer as três proposições que se seguem:

1. A única forma de realidade é o presente; só nele o real pode ser imediatamente encontrado, estando sempre nele contido total e perfeitamente.

2. O que é verdadeiramente real é independente do tempo, sendo portanto um e o mesmo em cada ponto do tempo.

3. O tempo é a forma intuitiva de nosso intelecto e, por isso, alheio à coisaem-si.

Estas três proposições são no fundo idênticas. Quem se apercebe claramente tanto da sua identidade, como de sua verdade, fez um grande progresso na filosofia, já que concebeu o espírito do idealismo transcendental.

Como é, em geral, cheia de consequiências a doutrina kantiana da idealidade do tempo e do espaço, que ele expôs de modo tão seco e singelo! Enquanto nada resulta da conversa fiada empolada, cheia de pretensão e intencionalmente incompreensível dos três conhecidos sofistas ${ }^{2}$, que atraem de Kant para si próprios a atenção de um público indigno dele. Pode-se dizer que antes de Kant estávamos no tempo e agora é o tempo que está em nós. No primeiro caso, o tempo é real e somos por ele consumidos como tudo que está no tempo. No segundo caso, o tempo é ideal: está em nós. Com isso cai em primeiro lugar a pergunta com referência ao futuro depois da morte. Pois eu não sou; logo não existe também mais nenhum tempo. É só uma aparência enganadora que me mostra um tempo que prossegue sem mim depois de minha morte: todas as três divisões do tempo, passado, presente e futuro, são da mesma maneira produtos meus e me pertencem, mas eu não pertenço a uma delas de preferência à outra. - Por outro lado, mais uma consequiência que se pode tirar da proposição de que o tempo não pertence ao ser em si das coisas é a de que, 
num certo sentido, o passado não é passado, mas tudo que alguma vez foi real e verdadeiro no fundo ainda tem de sê-lo, já que o tempo se assemelha a uma cachoeira de teatro que parece cair torrencialmente, enquanto, como uma mera roda, não sai do lugar. - Já há muito tempo, na minha obra principal, comparei analogamente o espaço com um vidro polido em facetas, que nos faz ver o que existe de modo simples numa reprodução inumerável. Mesmo se, diante do risco de tocar as raias do delírio, nos aprofundarmos ainda mais no assunto, pode nos ocorrer como se nós, numa presentificação bem viva de nosso próprio passado muito remoto, adquiríssemos uma convicção imediata de que o tempo não toca o ser próprio das coisas, mas é apenas interposto entre este e nós como um mero meio de percepção, com a retirada do qual tudo voltaria a existir. Por outro lado, também nossa faculdade de memória, tão fiel e viva, na qual aquilo que se passou de há muito conserva uma existência imperecível, dá testemunho de que em nós há igualmente algo que não envelhece e, conseqüentemente, não está no domínio do tempo.

A tendência capital da filosofia kantiana é provar a total diversidade do real e do ideal, depois de Locke já ter aberto caminho para isto. - Superficialmente, pode-se dizer que o ideal é a forma intuitiva, que se manifesta espacialmente, com todas as propriedades que nela são percebidas; o real, em contrapartida, é a coisa em e para si mesma, independente de ser representada na mente de um outro ou na nossa própria. Só que o difícil é traçar os limites entre ambos, embora seja justamente disto que se trata. Locke mostrou que tudo o que naquela forma é cor, som, lisura, aspereza, dureza, maciez, frio, calor etc., (qualidades secundárias) é meramente ideal e que, portanto, não pertence à coisa-em-si mesma, a saber, porque naquela forma não são dados o ser e a essência das coisas, mas apenas o agir da coisa e, de fato, um agir bem unilateral e determinado, a saber, aquele que se dá sobre a receptividade bem especificamente determinada dos nossos cinco órgãos dos sentidos, em virtude da qual o som não age sobre os olhos nem a luz sobre os ouvidos. De fato, o agir dos corpos sobre os órgãos dos sentidos consiste apenas em pô-los na sua atividade própria, quase como se eu puxasse um fio que pusesse o relógio musical a tocar. Em contrapartida, como real e pertencente à coisa-em-si mesma, Locke ainda deixou ficar a extensão, forma, impenetrabilidade, movimento ou repouso e número - que, por isso, chamou de qualidades primárias. Com um discernimento infinitamente superior, Kant mostrou mais tarde que 
essas propriedades também não pertencem à pura essência objetiva das coisas ou à coisa-em-si-mesma e, portanto, não podem ser simplesmente reais, porque são condicionadas pelo espaço, tempo e causalidade. Estes porém, e, de fato, segundo toda sua legalidade e índole, nos são dados e precisamente conhecidos antes de toda experiência. Assim, têm que estar pré-formadas em nós, assim como o modo específico de receptividade e atividade de cada um de nossos sentidos. De acordo com isso, já disse expressamente que aquelas formas são a quota de participação do cérebro na intuição, como as sensações específicas dos sentidos o são dos respectivos órgãos ${ }^{4}$. Já de acordo com Kant, o puro ser objetivo das coisas é portanto independente de nossa representação e de seu aparato. Que ele nomeia coisa-em-si e é, portanto, o próprio real em oposição ao ideal, algo total e completamente diferente da forma que se manifesta para nós intuitivamente e ao qual, devendo ser independente do espaço e do tempo, nem mesmo podem ser atribuídas duração e extensão, embora comunique a força de existir a tudo que tem extensão e duração. Também Espinosa apreendeu a questão em linhas gerais ${ }^{5}$, como pode ser visto na sua Ética, $\S 2$, prop. 16 com seu segundo corolário (e também prop. 18, escólio).

O real de Locke, em oposição ao ideal, é, no seu fundamento, a matéria, obviamente despida de todas as propriedades que ele põe de lado como secundárias, quer dizer, condicionadas por nossos órgãos dos sentidos; porém, de fato, algo que existe em si e por si como extenso etc. sendo a representação seu mero reflexo ou imagem em nós. Relembro aqui que eu provei (Sobre a quádrupla raiz, segunda edição, p. 77, e menos detalhadamente no Mundo como vontade e representação, vol. I, p. 9 e vol. 2, p. 48 ) que a essência da matéria consiste inteiramente no seu agir, e assim que a matéria é de ponta a ponta causalidade e que, uma vez que dela pensada como tal, deve ser abstraída toda qualidade particular e toda maneira específica de agir, ela é o agir ou a pura causalidade privada de toda determinação mais próxima, é a causalidade em abstrato. Para uma compreensão mais profunda peço ao leitor que se remeta às passagens citadas. Porém, apesar de só eu ter dado a prova correta, Kant já ensinara que toda causalidade é apenas uma forma de nosso entendimento, que portanto só está presente no e para o entendimento. De acordo com isso vemos agora aquele pretenso real de Locke, a matéria, ser reconduzido por este caminho totalmente ao ideal e, assim, ao sujeito, isto é, existir só na representação e para a representação. Já Kant retirara, por meio de sua expo- 
sição, a materialidade do real e da coisa-em-si: também para ele só restou um $\mathrm{X}$, totalmente desconhecido. Eu, porém, demonstrei por fim a vontade em nós, como o que é verdadeiramente real ou a coisa-em-si, a única que tem uma existência real independente da representação e de suas formas. Embora a tivessem até então, impensadamente, classificado como ideal. Vê-se a partir daí que Locke, Kant e eu estamos em íntima conexão, desde que nós, num período de quase dois séculos, expusemos o desenvolvimento gradual de uma marcha de pensamento coerente e mesmo homogênea. Devemos considerar ainda David Hume como um elo de ligação nesta cadeia, embora só no que se refere à lei da causalidade. A respeito dele e de sua influências devo ainda completar a exposição acima por meio do seguinte:

Locke, como também Condillac, que seguia suas pegadas com seus discípulos, mostram e indicam que, à sensação que entra num órgão dos sentidos, tem de corresponder uma causa fora de nosso corpo e, a seguir, que, às diferenças de tais efeitos (impressões nos sentidos), têm de corresponder também as diferenças de causas, e finalmente, também, quais possivelmente estas poderiam ser; é daí que resulta a distinção entre qualidades primárias e secundárias, acima mencionada. Com isso, elas estão concluídas, e surge agora para elas um mundo objetivo no espaço, de puras coisas-em-si, que é por certo incolor, inodoro, sem ruído, nem quente, nem frio etc. e todavia extenso, formado, impenetrável, móvel e calculável. Só que eles, como todos os filósofos anteriores, tomaram o axioma em virtude do qual aconteceu aquela passagem do interior para o exterior e toda aquela dedução e instalação das coisas-emsi, portanto, a lei da causalidade, como auto-evidente, não submetendo sua validade a nenhuma prova. Contra isto, Hume dirigiu seu ataque cético, pois punha em dúvida a validade daquela lei. Isto porque a experiência, a partir da qual, segundo aquela filosofia, todo nosso conhecimento deve originar-se, nunca pode fornecer a própria conexão causal, mas sempre a mera sucessão dos estados no tempo, portanto nunca uma conseqüência, mas uma mera sequiência, que, como tal, sempre se comprova ser apenas contingente e nunca necessária. Este argumento difícil de refutar, mas que já contradiz o bom senso, levou Kant a investigar a verdadeira origem do conceito de causalidade. Ele descobriu então que esta residia na forma essencial e inata do nosso próprio entendimento, portanto, no sujeito, não, porém, no objeto, já que não nos era trazido de fora. Mas, por meio disso, todo aquele mundo objetivo de Locke 
e Condillac foi trazido de novo para dentro do sujeito, pois Kant provou que o fio condutor para ele era de origem subjetiva. Assim, tão subjetiva quanto a própria impressão dos sentidos é a regra em conseqüência da qual uma impressão dos sentidos é concebida como efeito de uma causa. Esta causa é tão somente aquilo que é intuído como mundo objetivo, já que o sujeito admite um objeto que se encontra no exterior apenas graças à propriedade de seu intelecto que é a de pressupor uma causa para cada mudança; ele propriamente só o projeta para fora de si, num espaço preparado para esta finalidade, sendo tal espaço, ele próprio, um produto de sua constituição própria e originária, tanto quanto a impressão específica nos órgãos dos sentidos que dá ensejo que todo o processo ocorra. Deste modo, aquele mundo objetivo de coisas-em-si de Locke foi transformado por Kant num mundo de meros fenômenos no nosso aparato cognitivo e isto, de modo tão mais completo, na medida em que tanto o espaço no qual ele se manifesta, quanto o tempo, no qual ele passa, foram provados por Kant como sendo de inegável origem subjetiva.

Apesar de tudo isso, porém, Kant deixou, tal como Locke, que a coisaem-si subsistisse - quer dizer, que algo existisse independentemente de nossas representações, que, enquanto tais, só nos fornecem fenômenos - e que estivesse no fundamento destes fenômenos. Embora Kant, também aqui, tivesse certamente razão, não se pode derivar, no entanto, a justificação para isto dos princípios que estabeleceu. Aqui está o calcanhar de Aquiles de sua filosofia, e esta teve de perder, por meio da prova daquela inconsequiência, o reconhecimento já obtido de sua validade e verdade incondicionais; mas, em última instância, foi por isso injustiçada. Pois a admissão de uma coisa-em-si detrás dos fenômenos, de um caroço real sob tantas cascas, não é de nenhum modo inverídica, e seria muito mais absurda a negação dela. Mas apenas a maneira pela qual Kant introduziu uma tal coisa-em-si e procurou uni-la com seus princípios é que foi errônea. No fundo é apenas sua exposição (tomada esta palavra no seu sentido mais abrangente) da questão, não ela própria, é que foi derrubada pelos seus opositores e, neste sentido, pode-se dizer que a argumentação que se fez valer contra ele foi propriamente ad hominem e não ad rem ${ }^{6}$. Em todo caso, o provérbio indiano "não há lótus sem caule", aqui encontra de novo aplicação. Kant foi guiado pela verdade, sentida de modo seguro, que diz que detrás de cada fenômeno está um ser em si mesmo do qual o fenômeno recebe sua consistência e, portanto, que algo representado está 
por detrás da representação. Resolveu, porém, derivá-lo da própria representação por meio da consulta de suas leis que nos são a priori conhecidas, mas que, justamente por serem a priori, não podem levar a algo que seja independente ou diferente do fenômeno ou da representação; assim, para chegarmos a este algo, temos de seguir um caminho totalmente diferente. As inconseqüências em que Kant se enredou por meio da via errada que tomou em vista disso foram-lhe demonstradas por Gottlob Ernst Schulze, que explicou a coisa no seu estilo pesado e prolixo, primeiro anonimamente no Enesidemo e mais tarde na Crítica da filosofia teórica, vol. 2, p. 205 e ss.), contra o que Reinhold conduziu a defesa de Kant, embora sem particular sucesso, de modo que aqui temos que contentar-nos com o "haec potuisse dici et non potuisse refelli" ("isto poderia ser afirmado e não poderia ser refutado").

Quero aqui pôr em relevo claramente, de uma vez por todas, a meu modo, o propriamente essencial da questão que está no fundo de toda a controvérsia, independentemente da concepção que Schulze tem dela. Kant nunca forneceu uma rigorosa dedução da coisa-em-si, antes, tomou-a de seus predecessores, particularmente de Locke, e a conservou como algo de cuja existência não se pode duvidar, já que é algo auto-evidente; de uma certa maneira ele precisou fazer isso. A saber, de acordo com a descoberta de Kant nosso conhecimento empírico contém um elemento que é comprovadamente de origem subjetiva e um outro, para o qual isso não vale. Este último permanece portanto como objetivo, porque não há nenhuma razão para considerá-lo como subjetivo $^{7}$. De acordo com isso o idealismo transcendental de Kant nega a essência objetiva das coisas ou a realidade delas independente da nossa apreensão, certamente até onde se estende o a priori em nosso conhecimento. Não mais adiante, todavia, porque o fundamento para negá-la não vai mais longe. Ele deixa ficar o que está além disso e, assim, todas aquelas propriedades das coisas que não se deixam construir a priori. Pois a totalidade da essência dos fenômenos dados, quer dizer, o mundo corpóreo, não é de modo algum determinável por nós a priori, mas só o é a forma universal de seu fenômeno, e essa pode ser reduzida ao espaço, tempo e causalidade, junto com a conformidade a leis destas três formas. Em contrapartida, o que foi deixado indeterminado por aquelas três formas existentes a priori, aquilo portanto que é contingente em relação a elas, é a própria manifestação da coisa-em-si mesma. Assim o conteúdo empírico dos fenômenos, isto é, toda determinação mais próxima 
deles, toda qualidade física que neles aparece, não pode ser conhecida de outro modo a não ser a posteriori: essas propriedades empíricas (ou antes as suas fontes comuns) são pois deixadas para a coisa-em-si mesma como manifestações de seu próprio ser específico através da mediação de todas aquelas formas a priori. Esse a posteriori que aparece em cada fenômeno, como que envolto no a priori, mas que no entanto confere a cada ser seu caráter específico e individual, é, de acordo com isso, a matéria do mundo fenomênico em oposição à sua forma. Ora, essa matéria não pode de modo algum ser derivada daquelas formas do fenômeno que se prendem ao sujeito e que foram tão cuidadosamente buscadas por Kant e provadas corretamente por meio do sinal do apriorismo, mas ela, em contrapartida, ainda permanece depois da abstração de tudo que decorre dessas formas e é portanto estabelecida como um segundo elemento totalmente distinto do fenômeno empírico e como um acréscimo alheio àquelas formas. Por outro lado também essa matéria não provém, de modo algum, do arbítrio do sujeito cognoscente, mas antes contrapõe-se freqüentemente a ele. Logo, Kant não tem a menor dúvida em deixar essa matéria do fenômeno para a coisa-em-si mesma, vendo-a assim como vinda de fora; isto porque ela teria de vir de algum lugar ou, como se expressa Kant, tem de ter algum fundamento. Já que não podemos isolar aquelas propriedades só cognoscíveis a posteriori e não as podemos conceber inteiramente separadas e purificadas do que é certo a priori, pois aparecem sempre envoltas neste, então Kant ensina que conhecemos por certo a existência das coisasem-si, mas nada além disso e, portanto, só sabemos que elas são, mas não $o$ que são. É por isso que o ser da coisa-em-si fica para Kant como uma grandeza desconhecida, como um X. Pois a forma do fenômeno reveste e esconde sempre o ser da coisa-em-si mesma. Pode-se no máximo dizer que aquelas formas a priori pertencem sem distinção a todas as coisas enquanto fenômenos, já que surgem de nosso intelecto, mas que as coisas mostram ao mesmo tempo diferenças muito significativas. Assim, aquilo que determina estas diferenças, e portanto as diferenças específicas das coisas é a coisa-em-si mesma.

Vendo-se a coisa desta maneira, a admissão e a pressuposição da coisaem-si em Kant, abstraindo a subjetividade de nossas formas do conhecimento, parece legítima e bem fundamentada. No entanto, mostra-se insustentável, quando seu único argumento, a saber, o conteúdo empírico em todo fenômeno, é examinado corretamente e reconduzido à sua origem. Certamente, aliás, 
existe no conhecimento empírico e na sua fonte, a representação intuitiva, uma matéri $a^{8}$ independente da forma que nos é conhecida a priori. A próxima questão é se esta matéria tem uma origem objetiva ou subjetiva, desde que só no primeiro caso ela pode garantir a coisa-em-si. Vamos por isso até suas origens; não a encontraremos então em nenhum outro lugar a não ser na nossa impressão dos sentidos. Pois uma modificação que ocorre na retina do olho ou nos nervos auditivos ou na ponta dos dedos é o que introduz a representação intuitiva, quer dizer, põe em funcionamento todo aparato das nossas formas de conhecimento já prontas a priori, cujo resultado é a percepção de um objeto exterior. Aliás, a cada modificação sentida nos órgãos dos sentidos é aplicada, em primeiro lugar, a lei da causalidade por meio de uma necessária e inevitável função a priori do entendimento. Esta leva com sua segurança e certeza apriorística a uma causa daquela modificação, que, não estando no arbítrio do sujeito, apresenta-se então para ele como algo exterior, uma propriedade que só recebe sua significação por meio da forma do espaço, sendo este último, porém, igualmente acrescentado pelo próprio intelecto para essa finalidade. Através disso, portanto, aquela causa necessariamente pressuposta logo se apresenta intuitivamente como um objeto no espaço, que traz como suas propriedades as modificações por ela efetuadas em nossos órgãos dos sentidos. Todo este processo se encontra detalhada e profundamente exposto na segunda edição de minha dissertação Sobre o princípio de razão, § 21. Mas a impressão dos sentidos, que dá o ponto de partida para este acontecimento e que fornece indiscutivelmente toda a matéria para a intuição empírica, é de fato algo totalmente subjetivo; e como também o conjunto das formas de conhecimento, por meio das quais o mundo objetivo nasce de uma matéria e depois é projetado para fora, de acordo com a prova correta de Kant, têm sempre origem subjetiva; logo é claro que tanto a matéria como a forma da intuição subjetiva surgem a partir do sujeito. De acordo com isso todo nosso conhecimento empírico se decompõe em duas partes, que têm ambas sua origem $\mathrm{em}$ nós próprios, a saber, a impressão dos sentidos e as formas dadas a priori e, portanto, nas formas postas nas funções de nosso intelecto ou cérebro, que são: espaço, tempo e causalidade, às quais Kant, além disso, acrescentou ainda outras onze categorias do entendimento, provadas por mim como supérfluas e inadmissíveis. Conseqüentemente, a representação intuitiva e o nosso conhecimento empírico que nela se apóia não oferece verdadeiramente ne- 
nhum elemento para a inferência de coisas em si, e Kant não estava autorizado, de acordo com seus princípios, a admiti-las. Como todos as antecessoras, também a filosofia de Locke tomou a lei da causalidade como algo absoluto, estando por isso justificada a inferir, a partir da impressão dos sentidos, coisas externas efetivamente existentes e independentes de nós. Esta passagem do efeito para a causa é todavia o único caminho para ir diretamente do que é dado subjetiva e internamente ao se apresenta externa e objetivamente. Porém, depois que Kant reivindicou a lei da causalidade para a forma de conhecimento do sujeito, esse caminho não ficou mais aberto para ele. Ele próprio também advertiu suficientemente para não se fazer um uso transcendente da categoria da causalidade, quer dizer, um uso que ultrapasse a experiência e a sua possibilidade.

A coisa-em-si, com efeito, nunca mais pode ser alcançada por essa via e principalmente pelo caminho do puro conhecimento objetivo que, como tal, permanece sempre como representação, enraízando-se assim no sujeito e não podendo nunca fornecer algo realmente diverso da representação. Mas só se pode chegar à coisa-em-si se, de uma vez por todas, desloca-se o ponto de vista, a saber, se, ao invés de partir, como se fez até agora, do que representa, se parte, por uma vez, daquilo que é representado. Isto porém só é possível por meio de uma única coisa que, como tal, é acessível a cada um de dentro e assim é dada de modo duplo: é o seu próprio corpo que existe no mundo objetivo também como representação no espaço, mas que, ao mesmo tempo, se anuncia para a própria consciência de si como sendo vontade. Desse modo, porém, a vontade fornece a chave, primeiramente, para o entendimento de todas as suas ações e movimentos produzidos por causas (aqui, motivos) exteriores, os quais, sem esta penetração interna e imediata no seu ser, pernaneceriam para nós tão incompreensíveis e inexplicáveis como as modificações dos demais corpos, dados a nós apenas na intuição objetiva, as quais ocorrem de acordo com as leis da natureza e como exteriorizações das forças da natureza. Em segundo lugar, a vontade dá a chave para a compreensão do substrato permanente de todas essas ações, no qual se enraízam as forças para realizálas - portanto, a chave para o próprio corpo. Esse conhecimento imediato, que cada um tem do ser de seu próprio fenômeno que é, além disso, dado a ele só na intuição objetiva, do mesmo modo que todos os outros, tem em seguida de ser transposto analogicamente para todos fenômenos restantes, somente da- 
dos da última maneira, tornando-se então a chave para o conhecimento do ser interno das coisas, quer dizer, da coisas-em-si mesma. Só se pode, portanto, chegar a esta por um caminho totalmente diferente do conhecimento objetivo, que permanece mera representação, a saber, pedindo ajuda à autoconsciência do sujeito do conhecimento que só se apresenta como indivíduo animal e fazendo dela o intérprete da consciência das outras coisas, isto é, do intelecto intuicionante. Esse é o caminho que percorri e é o único certo, o portal estreito para a verdade. (...)

\section{Notas}

1. Ver $\S 32$ da obra de Schopenhauer A Quádrupla Raiz do Princípio de Razão Suficiente (N.T.).

2. “A Crítica da Razão Pura transformou a ontologia em dianoiologia" (Nota do discípulo Frauenstädt, numa edição crítica à obra do mestre) (N.T.).

3. "Os três conhecidos sofistas"a que Schopenhauer se refere são os filósofos Fichte, Schelling e Hegel, idealistas, seus contemporâneos. Sofistas, porque exerciam a profissão de professores de filosofia, vivendo dessa sua função. Ora, Schopenhauer faz uma crítica da filosofia como profissão em vários momentos de sua obra e, especialmente, no texto dos Parerga, Sobre a Filosofia Universitária (Trad. Maria Lúcia Cacciola e Márcio Suzuki, Ed. Polis, São Paulo, 1980), onde condena "os que vivem da filosofia e não para a filosofia" (N.T.).

4. "Do mesmo modo que é nosso ôlho que produz o verde, o vermelho e o amarelo, assim também é o nosso cérebro que produz o espaço, o tempo e a causalidade, (cujo abstrato objetivo é a matéria) - A minha intuição de um corpo no espaço é o produto de minha função sensorial e cerebral mais X" (Nota de Frauenstädt) (N.T.).

5. Espinosa diz na proposição 16 da primeira parte da Ética , corolário II "que as idéias que temos dos corpos exteriores indicam mais a constituição do nosso corpo do que a natureza dos corpos exteriores" (grifo meu) e, no escólio à proposição XVIII, explicita que a concatenação das idéias referentes à natureza dos corpos exteriores se dá segundo a ordem e a concatenação das afecções do corpo; essa concatenação envolve apenas a natureza dos corpos exteriores, não explicando a natureza desses corpos. Aí ele se remete à prop. 16 (N.A.). 
6. $\mathrm{O}$ argumento ad hominem vale apenas contra o adversário que se combate, seja ele fundado sobre um erro, uma inconseqüência ou uma concessão do adversário, seja que ele vise tal detalhe particular à individualidade ou à doutrina deste. (Dicionário Lalande). $\mathrm{O}$ argumento ad rem se refere à própria questão, tendo pois valor objetivo (N.T.).

7. Toda coisa tem duas espécies de propriedades: aquelas que podem ser conhecidas a priori e aquelas que só podem ser conhecidas a posteriori; as primeiras nascem do intelecto que as concebe, as segundas a partir do ser em si das coisas, que é aquilo que encontramos em nós como sendo vontade (N.A.).

8. Por matéria estamos traduzindo a palavra alemã Stoff, que quer dizer matéria, massa, algo informe; esta palavra corresponde ao francês étoffe e ao português estofo, material de que algo é feito, recheio ou conteúdo. Talvez Schopenhauer empregue aqui esta palavra ao invés de matéria para evitar que isto que se refere ao em-si não seja considerado como a matéria, conceito bem determinado.., e que se refere ao mundo como representação (N.T.). 